\title{
Production of Disease-Free Olive Seedlings with Artificial Intelligence and Biotechnological Methods
}

\author{
S. Galatali, M. A. Balci, O. Akguller, and E. Kaya
}

\section{ABSTRACT}

It is an inevitable fact that the applications of machine learning and artificial intelligence technologies in agricultural biotechnology approaches, whose applications are increasing rapidly in almost every field, will have an important place in determining the future fate of agriculture. Applications in which artificial intelligence is adapted to biotechnological processes such as breeding, in vitro culture studies, germplasm preservation, disease-free plant production, genetic transformation, and other genetic analyzes are becoming increasingly common. In the current study is highlighted the potential benefits between artificial intelligence and agricultural technologies. As with many plant species, viral diseases have negative effects on fruit yield, life span, and quality of olive varieties, which are important in economy. Elimination of viruses from the plant with traditional methods is quite laborious, takes a lot of time, and often fails to produce successful results. However, new protocols have been developed to eliminate persistent pathogens. These protocols include techniques such as heat application (thermotherapy), chemical therapy (chemotherapy), tissue culture methods (meristem culture). When these techniques are applied alone or together, it may be possible to obtain anti-virus plants. Artificial intelligence technology will make it possible to benefit from the method to be used in the most efficient way by revealing which of these biotechnological methods can be used in the most effective and optimal conditions, and the possible advantages and disadvantages as a result of comparing with others.

Keywords: Artificial Intelligence, biotechnology, Olea europaea L. plant viruses.

\section{INTRODUCTION}

Machine learning and artificial intelligence, which are the computer programming sciences for digital platforms such as computer and smartphone to learn from data, have begun to be common applied in in vitro-based and/or classical plant breeding studies for evaluation of the data flow obtained from plant observed phenotypes to DNA sequences. Machine learning methods can be divided into three classes: deep learning models, nonlinear and linear algorithms and supervised models. In plant biotechnology, there are different process for application of non-linear nonparametric machine learning algorithms such as random arrangement (RA), deep neural networks (DNN), artificial neural networks (ANN), support vector machines (SVM) and convoluted neural networks (CNN) [1]. Distorted data sets obtained by photo viewing data or sequencing data, can be evaluated via machine learning algorithms [2]. DNA sequencing data can be used in machine learning models to identify and classify displaceable elements [3]. Using machine learning algorithms, breeders can predict multiple dependent variables (multiple outputs) through variable combinations of multiple inputs in a single model and decrease the analysis required.
Published Online: June 13, 2021

ISSN: 2684-5199

DOI: $10.24018 /$ ejbio.2021.2.3.172

\section{S. Galatali}

Mugla Sitki Kocman University, Mugla, Tukey.

(e-mail: selingalatali@mu.edu.tr)

M. A. Balci

Mugla Sitki Kocman University,

Mugla, Tukey.

(e-mail: mehmetalibalci@mu.edu.tr)

O. Akguller

Mugla Sitki Kocman University,

Mugla, Tukey.

(e-mail: oakguller@mu.edu.tr)

E. Kaya*

Mugla Sitki Kocman University,

Mugla, Tukey.

(e-mail: ergunkaya@ ${ }^{@}$ mu.edu.tr)

*Corresponding Author
Olive (Olea europaea L.), originated from above Mesopotamia and southwest of Asia including part of Turkey's Southeastern Anatolia Region and Syria. Taking the olive into culture started on the eastern shores of the Mediterranean approximately $3000 \mathrm{BC}$ and made it one of the unique fruit cultivars cultivated in this area [4]. Today, the Mediterranean area supports $98 \%$ of the world's olive oil production with nearly 2000 culture varieties [5]. Spreading to variable regions from origin centre where they were cultivated, ensures olives one of the most considerable horticultural plant species and makes the studies required for conserving its germplasm a very significant priority. Recently studies on mitochondrial analysis show that wild olive species from Mediterranean basin originated from two different locations, one in Maghreb and the other in the Near East [6]. It is indicated that the olives cultivation began approximately 5500 years ago, after the human migration from the wild Mediterranean olive known as "Oleaster", which began to spread throughout North Africa and Southern Europe. The original development of the olive genetic resources is based on the selection and characterization of the best trees, which is the beginning of the clonal genetic basis of the cultivars in addition to the vegetative multiplication [7]. 
As with many plant species, viral diseases have negative effects on fruit yield, life span, and quality of olive varieties, which are important in our country's (Turkey) economy (Fig. 1). These negative effects, which can lead to tree losses, may occur when the plant is infected by viruses through insects and/or birds vectors due to reasons such as plant injury. Types of viruses that have been detected in the Mediterranean climate zone in which our country is located so far and that cause infection in olive trees are Olive vein yellowing associated potexvirus (OVYaV), Olive Latent 2 Bromovirus (OLV2), Olive latent sobemovirus 1 (OLV1), Olive latent ringspot nepovirus (OLRV), Cucumber mosaic cucumovirus (CMV), Tobacco mosaic tobamovirus (TMV), Arabis mosaic nepovirus (ArMV), Strawberry latent ringspot nepovirus (SLRSV), and Cherry leaf roll nepovirus (CLRV) [8]-[13].

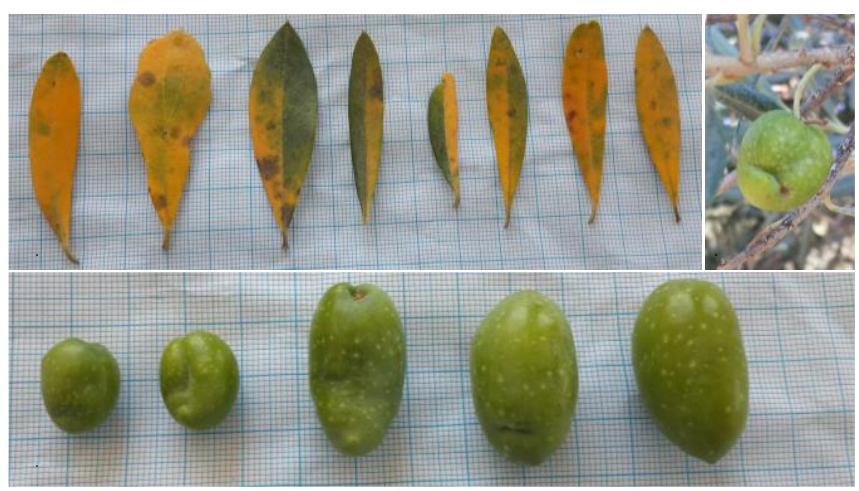

Fig. 1. Symptomatic effects of Olive vein yellowing associated potexvirus (OVYaV) on leaf and fruit in "Memecik" olive cultivars collected from Muğla/Köyceğiz.

Olive trees are an important carrier of viruses that cause viral infections, and in our country, olive producers do not pay attention to whether the olive trees from which the cuttings are carrying viruses in their cutting works for seedling production [14]. In this context, it is necessary to examine the plantation of our country in terms of viral diseases, to identify those infected with the disease and to diagnose existing viral diseases, and thus to fight virus diseases effectively. Since there is no chemical method that can be used in the control of plant viral diseases, the main goal of the fight is to prevent the spread of existing viral diseases by using biotechnological methods to produce virus-free and disease-free seedlings.

In addition to traditional methods such as destroying the sources of virus infection, directly protecting, and fighting the vectors that carry the virus from plant to plant, growing plants resistant to virus infections, treatment with various biotechnological methods (thermotherapy, chemotherapy) or advanced tissue culture methods such as purification using meristem culture. Elimination of viruses from the plant with traditional methods is quite laborious, takes a lot of time, and often fails to produce successful results [15]. However, new protocols have been developed to eliminate persistent pathogens. These protocols include techniques such as heat application (thermotherapy), chemical therapy (chemotherapy), tissue culture methods (meristem culture). When these techniques are applied alone or together, it may be possible to obtain anti-virus plants.
Meristem culture has been used for the purification of plants from viruses since the 1930s [16], [17]. This technique utilizes the difference in the amount of virus particles in different plant cells. The apical end and root meristem cells of the plant are very small due to their continuous division characteristics. Hence the probability of viruses being present in these cells is very low, these tissues are highly preferred in the production of virus-free and disease-free plants [18]. Although it cannot be stated that these parts of the plant are completely free of viruses, the treatment efficiency can be increased by applying different treatment options together (i.e., in conjunction with each other) [19].

The treatment of plant viruses with thermotherapy on one hand is based on the fact that the virus concentration decreases towards the top of the plant, and on the other hand, it inhibits the reproduction and diffusion of the plant virus due to the increase in temperature. This technique can also be applied in conjunction with meristem culture and chemotherapy [20]. It has been reported that this treatment method has been used in combination with chemotherapy in the treatment of apical parts (parts larger than the meristem) with meristem culture since the 1960s [21], [22]. It has also been reported that the apical portions treated in this way are still used in virus-free plant recovery [23].

Conventionally, developed as an alternative to the prevention and elimination of viruses and plant diseases and often preferred in the literature, in vivo, and in vitro thermotherapy treatments are used to eliminate several plant viruses [24]. Postman and Mehlenbacher [25] achieved the elimination of ApMV virus, which they determined by ELISA method, on hazelnut varieties from different countries by thermotherapy technique. Manganaris et al. [26] developed an effective thermotherapy protocol for the eradication of PNRSV and PPV from nectarines and emphasized that this could be extended by applying it to commercial Prunus spp. varieties.

In the cryotherapy method, the isolated meristems are subjected to cryoprotective processes in the most appropriate way, treated with liquid nitrogen $\left(-196^{\circ} \mathrm{C}\right)$, and then transferred to the appropriate regeneration medium and their development is observed. The basis of the cryopreservation technique is that the transport of viral particles to the meristematic dome is difficult due to the lack of advanced conduction tissues in the meristems, and thus regenerated new tissues can be virus-free. Cryotherapy method is an up-to-date technique developed for virus elimination from infected plants. Using the cryotherapy method, potato (Solanum tuberosum L., Solanaceae), sweet potato (Ipomea batatas [L.] Lam., Convolvulaceae), grape (Vitis vinifera L.; Vitaceae), citrus fruits (Citrus spp., Rutaceae) and plum (Purunus spp., Rosaceae), blackberry (Rubus idaeus L.; Rosaceae) and banana (Musa spp., Musaceae) have been used to eradicate different viruses infected plants [27]-[31].

Nowadays, thanks to newly developed technologies, the use of biotechnological methods is increasingly common in the treatment of these and similar pathogen-based diseases, which cause significant losses in plants. The limitation in these applications is the different application requirements for each plant species and even variety. Thanks to 
technologies such as machine learning and artificial intelligence, it is possible to both save time and choose the effective protocol. Artificial intelligence technology will make it possible to benefit from the method to be used in the most efficient way by revealing which of these biotechnological methods can be used in the most effective and optimal conditions, and the possible advantages and disadvantages as a result of comparing with others.

\section{ARTIFICIAL INTELLIGENCE, MACHINE LEARNING AND DATA SCIENCE}

Although artificial intelligence, machine learning, and data science are heavily intertwined, they are related but different fields. The relationship between them is shown in Fig. 2. While artificial intelligence is concerned with giving machines the ability to imitate human behavior, particularly cognitive functions; machine learning can be thought of as one of the tools of artificial intelligence and provides machines with learning ability. your manuscript electronically for review.

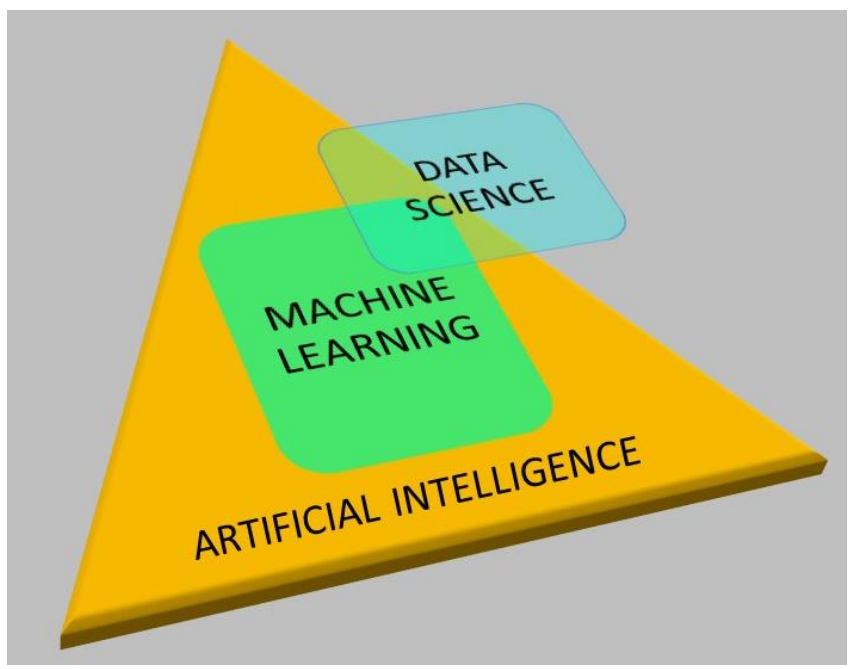

Fig. 2. Schematic representation of the relationship between artificial intelligence, machine learning, and data science.

\section{A. Artificial Intelligence}

Every algorithm has inputs and outputs. The data are processed with the functions specified in the algorithm and a result is presented. Artificial intelligence, on the other hand, should have the ability to correctly interpret external data, learn from these data and use these capabilities to fulfill certain goals and tasks through flexible adaptation [32]. Any artificial intelligence optimizes its functions by analyzing inputs that provide data, maximizing its success on the target. Since the first introduction of artificial intelligence, various approaches have been applied to create machines that think. These approaches include symbolic logic, logicbased, knowledge-based, flexible computation, and statistical learning [33].

\section{B. Machine Learning}

Machine learning can be considered as one of the tools of artificial intelligence as shown in Fig. 2. The results of an experienced situation provide the ability to learn. The schematic representation of the operation between traditional programming algorithms and machine learning is given in Fig. 3 [34]. A program converts input signals into output signals using pre-determined rules and relationships in a computer script. Machine learning algorithms use both known input and output as training data to find a model that converts input into output.

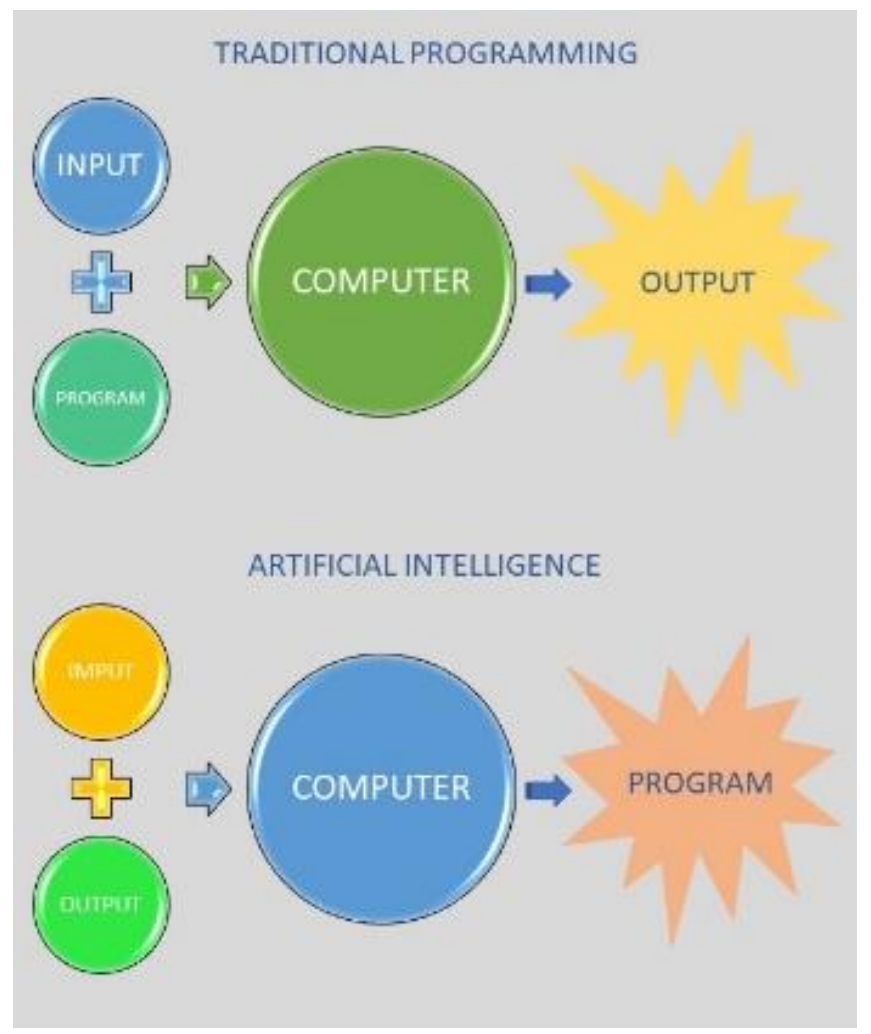

Fig. 3. Schematic representation of the difference in functioning in artificial intelligence and traditional programming.

\section{Data Science}

Data science, also known as data mining, is a field of study that provides resources for areas such as artificial intelligence, machine learning and statistics. For example, data science is the work done to collect and parse the data of a store's customers and transform it into clean data that can be used on artificial intelligence. It is mostly used in conjunction with machine learning in terms of the need for large amounts of data. Data science uses learning algorithms such as decision trees, neural networks, k-nearest neighbors, and k-mean clustering.

\section{ARTIFICIAL INTELLIGENCE APPLICATIONS}

The process of collecting and analyzing data, which is an essential part of scientific research, gained momentum after the 20th century with the invention of the computer and the digitalization of data. With powerful and comprehensive package programs used for statistical analysis, data processing has also become easier. Artificial intelligence applications differ positively from traditional statistical techniques in terms of contributing to the processes such as the method to be followed or the interpretation of the findings [35]. 


\section{A. Artificial Intelligence Applications in Basic Sciences}

The main point that makes artificial intelligence successful is the learning ability that allows it to keep up with these changes in natural sciences. In addition to encountering artificial intelligence studies in all sciences dealing with nature such as mathematics, engineering, medicine, environment, biology, astronomy, physics, chemistry, geology, meteorology, and genetics, it is seen that its use in daily life is increasing. The most known of these is the face recognition feature in smartphones. By processing the image data obtained from the phone's camera with artificial intelligence algorithms, the user of the phone can be identified or processes such as identifying and autotagging the person you have previously tagged in a photo can be performed [36-37]. When the same technology is trained with different data sets, it can turn into a useful tool in that area. For example, Golgiyaz et al. [38] conducted a study on the estimation of the flue gas temperature with features obtained from the flame image in a coal-fired burner and developed a model that predicted with $97 \%$ accuracy.

TABLE I: THE REPORTS OF SOME ARTIFICIAL NEURAL NETWORKS STUDIES INCORPORATED IN THE AGRICULTURE

\begin{tabular}{|c|c|c|}
\hline Technology and System & Purpose & References \\
\hline $\begin{array}{c}\text { Artificial neural } \\
\text { networks and expert } \\
\text { systems }\end{array}$ & $\begin{array}{c}\text { Predicting crop nutrition } \\
\text { levels }\end{array}$ & [39] \\
\hline $\begin{array}{c}\text { Expert systems } \\
\text { (COMAX, COtton } \\
\text { Management eXpert) }\end{array}$ & $\begin{array}{l}\text { Increasing the production of } \\
\text { cotton crop }\end{array}$ & [40] \\
\hline $\begin{array}{l}\text { Expert systems } \\
\text { (COTFLEX) }\end{array}$ & $\begin{array}{l}\text { Associated the farm and Crop } \\
\text { databases to support } \\
\text { significant data relation the } \\
\text { cotton crop to the grower so } \\
\text { that it becomes easy for the } \\
\text { farmer to take crucial } \\
\text { decisions. }\end{array}$ & [41] \\
\hline $\begin{array}{l}\text { Expert systems } \\
\text { (SMARTSOY - } \\
\text { SOYGRO) }\end{array}$ & $\begin{array}{l}\text { Generating recommendation } \\
\text { for soybean crop is dependent } \\
\text { on calculation and prediction } \\
\text { of the cost and damage rate to } \\
\text { treat the plant and gain the } \\
\text { yield. }\end{array}$ & [42] \\
\hline $\begin{array}{c}\text { Expert system } \\
\text { (PRITHVI, based on } \\
\text { fuzzy logic) }\end{array}$ & $\begin{array}{l}\text { The system, designed for } \\
\text { explicitly of Soybeans crop. }\end{array}$ & [43] \\
\hline $\begin{array}{l}\text { Expert systems } \\
\text { (POMME) }\end{array}$ & $\begin{array}{l}\text { Helping the farmers for spray } \\
\text { in chemicals (insecticide) on } \\
\text { the apple to prevent the } \\
\text { disturb due to atmosphere and } \\
\text { insects. }\end{array}$ & [44] \\
\hline ANN algorithms & $\begin{array}{c}\text { Estimating soil moisture in } \\
\text { Paddy fields }\end{array}$ & [45] \\
\hline ANN algorithms & $\begin{array}{l}\text { Predicting of spatial water } \\
\text { distribution in the subsurface }\end{array}$ & [46] \\
\hline
\end{tabular}

Chaudhuri et al. conducted a study on the predictability of high-intensity earthquakes with artificial intelligence for the Indo-Himalayan border region. The researchers who applied a neural fuzzy logic inference system, which is a mixed model, obtained a model with a prediction accuracy of $99.4 \%$ [46].

Greenhouse gas emissions, which are known to be effective in global temperature increase, are increasing day by day. It is important to make accurate predictions for the future in determining the measures to be taken to eliminate the negative effects it creates in our environment and to protect the environment. Pabuccu and Bayramoglu conducted their study, $\mathrm{CO}_{2}$ emissions for Turkey's estimation, at 2020-2025-2030 years have used artificial neural networks. Estimates according to respectively 740.33 million tons this year (Mt), 1039.32 Mt and 1244.13 Mt values that will be the Turkey's Paris, he has been committed for 2030 Climate Summit 929 Mt, they could be out on the $\mathrm{CO}_{2}$ content. It is clear that the use of renewable energy sources is a good alternative to reduce $\mathrm{CO}_{2}$ emissions [47]. However, feasibility studies are also important in this regard, as in every investment. In order to find answers to questions such as from what source, where and to what extent the power plant where the investment will be made, studies are carried out on artificial intelligence models. For example, the use of artificial intelligence can be observed in determining the control parameters of a photovoltaic power plant [48] or calculating the wind potential of a region [49].

\section{CONCLUSION}

Image processing and artificial intelligence algorithms are also used to detect plant diseases that cause serious economic losses to producers. Alruwaili et al. classified some diseases in olive leaves using deep learning techniques in their study [50]. As a result of their study, they stated that they achieved a general accuracy rate of $99.11 \%$. In addition, there are commercial examples of agricultural machines that use artificial intelligence technology today. A Technology company can perform the imaging and spraying process simultaneously thanks to the withdrawable type of equipment it produces. Herbicide can be applied to weeds detected while on the move and drug can be applied to the cultivated plant. In this way, it avoids unnecessary practices and exhibits a more environmentally friendly approach.

\section{ACKNOWLEDGMENT}

The study was supported by Mugla metropolitan municipality, Department of Agricultural Services.

\section{REFERENCES}

[1] H. Zheng, W. Li, J. Jiang, Y. Liu, T. Cheng, Y. Tian, Y. Zhu, W. Cao, Y. Zhang and X.A. Yao. "Comparative Assessment of Different Modeling Algorithms for Estimating Leaf Nitrogen Content in Winter Wheat Using Multispectral Images from an Unmanned Aerial Vehicle," Remote Sensing, vol. 10, no. 2. pp. 2026, 2018.

[2] H. Hu, A. Scheben and D. Edwards. "Advances in Integrating Genomics and Bioinformatics in the Plant Breeding Pipeline," Agriculture, vol. 8, no. 6. pp. 75, 2018.

[3] S. Orozco-Arias, G. Isaza and R. Guyot. "Retrotransposons in Plant Genomes: Structure, Identification, and Classification through Bioinformatics and Machine Learning," International Journal of Molecular Science, vol. 20, pp. 3837, 2019

[4] D. Zohary and P. Spiegel-Roy. "Beginnings of fruit growing in the old world," Science, vol. 187, no. 4174. pp. 319-327, 1975.

[5] G. Bartolini and R. Petruccelli. Classification, Origin, Diffusion, and History of the Olive, Rome, Food and Agriculture Organization of the United Nations, 2002, pp. 43

[6] G. Besnard and A. Berville. "On Chloroplast DNA Variations in the Olea europaea L. Complex: Comparison of RFLP and PCR Polymorphisms," Theoretical and Applied Genetics, vol. 104, pp. 1157-1163, 2002.

[7] G. Besnard, P. Baradat, D. Chevalier, A. Lagmount and A. Berville. "Genetic differentiation in the olive complex (Olea europaea) 
revealed by RAPDs and RFLPs in the rRNA genes," Genetic Resources and Crop Evolution, vol. 48, pp. 165-182, 2001.

[8] E. Pacini and M. Cresi. "Viral Particles in Developing Pollen Grains of Olea europaea L," Plant Diseases, vol. 57, pp. 13-29, 1978.

[9] M. Marte, M.F. Cadani, V. Savino and E. Rugini. "Strawberry Latent Ringspot Virus AssociatedWith a New Disease of Olive in Central Italy," Plant Disease, vol. 70, pp. 171-172, 1986.

[10] M.A. Castellano, A.D. Eranco and G.P. Martelli. "Electron Microscopy of Two Olive Viruses in Host Tissue," Plant Diseases, vol. 68 , no. 12. pp. 57-12, 1987.

[11] H.E. Waterworth and R.L. Monroe. "Graft Transmission of Olive Sickle Leaf Disorder,” Plant Diseases, vol. 59, pp. 366-367, 1988.

[12] G.P. Martelli, V. Savino, B. Di Terlizzi, L. Catalano, S. Sabanadzovic and N. Greco. "Viruses and of olive in Apulia (Southern Italia)," Acta Hortuculture, vol. 386, pp. 569-573, 1995.

[13] E. Triolo, A. Materazzi and S. Toni. "An Isolate of Tobacco Mosaic Tobamovirus From Olea europaea L.," Advances in Hortucultural Science," vol. 10, no. 1. pp. 39-45, 1996.

[14] O. Beler and S. Acıkgoz. "Determination of some viral diseases seen in olive nurseries and trees in Aegean and Marmara Regions by ELISA Test," Journal of ADU Faculty of Agriculture, vol. 2, no.1. pp. $79-84,2005$.

[15] M. Ravelonandro, N. Minoiu and R. Scorza. "Investigations of Potential Environmental Impacts in the Release of Transgenic Plums," Acta Horticulturae, vol. 657, pp. 325-329, 2004.

[16] J.H. Dodds and L.W. Roberts. "Experiments in Plant Tissue Culture," Cambridge University Press, USA, pp.113-121. 1986.

[17] S.A. Nehra and K.K. Kartha. 1994. "Meristem and Shoot Tip Culture: Requirements and Applications," In: Vasil, I., Thorpe, T.A. (Eds.), Plant Cell and Tissue Culture, Dordrecht, Netherlands: Kluwer Academic Publishers, pp. 37-70.

[18] B. Burun. Plant Biotechnology Department 6, Disease-Free Plant Production, Selçuk University Press, 2001. pp. 190-210.

[19] J.L. Sherwood. "Applied Aspect of Plant Regeneration," In: Dixon, D. A., Gonzales, R.A., (Eds.), Plant Cell Cultur, A Ptactical Approach, pp. 135-138. 1993.

[20] S. Spiegel, A. Stein and Y. Tam. "In vitro Thermotherapy of Rosaceous Fruit Trees," Acta Horticulturae, vol. 386, pp. 419-420, 1995.

[21] R. Galzy. "Confirmation de la Nature Virale du Court-Noue de la Vigne par Desessais De Thermotherapie sur des Cultures in vitro," Comptes Rendus des Seances de 1 Academie des Sciences, vol. 253, pp. 706-708, 1961.

[22] B. Kassanis. "Heat Therapy of Virus-Infected Plants," Annals Applied Biology, vol. 41, pp. 470-74, 1954.

[23] B. Krizan and E. Ondursikovsa. "Thermotherapy of Apricot Cultivars," Acta Horticulturea, vol. 839, pp. 269-274, 2009.

[24] E. Knapp, V. Hanzer, D. Mendonça, A. da Câmara Machado, H. Katinger and M. Laimer de Câmara Machado. "Improved virus detection in rosaceous fruit trees," In vitro, Plant Cell, Tissue and Organ Culture, vol. 52, pp. 3-6, 1998.

[25] J.D. Postman and S.A. Mehlenbacher. "Apple mosaic virus in hazelnut germplasm," Acta Horticulturae, vol. 351, pp. 601-609, 1994.

[26] G.A. Manganaris, A.S. Economou, J.N. Boubourakas and N.I. Katis. "Elimination of PPV and PNRSV Through Thermotherapy and Meristem-Tip Culture in Nectarine," Cell Biology and Morphogenesis, vol. 22, pp. 195-200, 2003.

[27] G. Faccioli and A. Colombarini. "Correlation of potato virus S and virus $\mathrm{M}$ contents of potato meristem tips with the percentage of virusfree plantlets produced in vitro," Potato Research, vol. 39, pp. 129140, 1996.

[28] M. Brison, M-T. Boucaud, A. Pierronnet and F. Dosba. "Effect of cryopreservation on the sanitary state of a cv. Prunus rootstock experimentally contaminated with Plum Pox Potyvirus," Plant Science, vol. 123, pp. 189-196, 1997.

[29] B. Helliot, B. Panis, Y. Poumay, R. Swenen, P. Lepoivre and E. Frison. "Cryopreservation for the elimination of cucumber mosaic and banana streak viruses from banana (Musa spp.)," Plant Cell Reports, vol. 20, pp. 1117-1122, 2002.

[30] Q.C. Wang, M. Munir, P. Li, R. Gafny, I. Sela and E. Tanne. "Elimination of grapevine virus A (GVA) by cryopreservation of in vitro-grown shoot tips of Vitis vinifera L.," Plant Science, vol. 165, pp. 321-327, 2003.

[31] R. Infante and N. Fiore. "Combined effect of thermotherapy and in vitro shoot culture on the Grapevine leafroll associated virus 2 Red Globe strain affecting 'Red Globe' vines,' Journal of Food, Agriculture \& Environment, vol. 7, no. 3-4. pp. 274 - 277, 2009.

[32] A. Kaplan and M. Haenlein. "Siri, Siri, in my hand: Who's the fairest in the land? On the interpretations, illustrations, and implications of artificial intelligence," Business Horizons, vol. 62, no.1. pp. 15-25, 2018.

[33] R. Hoehndorf and N. Queralt-Rosinach. "Data Science and Symbolic AI: Synergies, Challenges and Opportunities," Data Science, vol. 1, pp. 27-38, 2017.

[34] V. Kotu and B. Deshpande. Data Science: Concepts and Practice. 2. Edition. Elsevier, USA. 2019.

[35] E. Brent. "Designing Social Science Research with Expert Systems," Anthropological Quarterly, vol. 62, no. 3. pp. 121-130, 1989.

[36] S. Chaudhuri, A.R. Chowdhury and P. Das. "Implementation of Sugeno: ANFIS for forecasting the seismic moment of large earthquakes over Indo-Himalayan region," Natural Hazards, vol. 90, no. 1. pp. 391-405, 2017

[37] M.O. Derawi. Smartphones and Biometrics. PhD Thesis, Gjøvik University College. Norway2012.

[38] S. Golgiyaz, M.F. Talu and C. Onat. "Prediction of Flue Gas Temperature Using Image Processing and Machine Learning,' European Journal of Science and Technology, vol. 16, pp. 283-291, 2019.

[39] H. Song and Y. He. Crop nutrition diagnosis expert system based on artificial neuralnetworks, Third International Conference on Information Technology and Applications (ICITA'05), 2005. Sydney, NSW.

[40] H. Lemmon. "Comax: an expert system for cotton crop management," Science, vol. 233, no. 4759. pp. 29-33, 1986.

[41] N.D. Stone and T.W. Toman. "A dynamically linked expert-database system for decision support in Texas cotton production," Computers and Electronics in Agriculture, vol. 4, no. 2. pp. 139-148, 1989.

[42] W.D. Batchelor, R.W. McClendon, D.B. Adams and J.W. Jones. "Evaluation of SMARTSOY: an expert simulation system for insect pest management," Agricultural Systems, vol. 31, no. 1. pp. 67-81, 1989.

[43] C. Prakash, A.S. Rathor and G.S.M. Thakur. "Fuzzy Based Agriculture Expert System for Soyabean,” pp. 1-13, 2013.

[44] J. Roach, R. Virkar, C. Drake and M. Weaver. "An expert system for helping apple growers," Computers and Electronics in Agriculture, vol. 2, no. 2. pp. 97-108, 1987.

[45] C. Arif, M. Mizoguchi, B.I. Setiawan and R. Doi. "Estimation of soil moisture in paddy field using Artificial Neural Networks," International Journal of Advanced Research in Artificial Intelligence, vol. 1. no.1. pp. 17-21, 2012.

[46] S. Chaudhuri, A.R. Chowdhury and P. Das. "Implementation of Sugeno: ANFIS for forecasting the seismic moment of large earthquakes over Indo-Himalayan region," Natural Hazards, vol. 90, no. 1. pp. 391-405, 2017.

[47] H. Pabuccu and T. Bayramoglu. "CO2 Emissions Forecast with Neural Networks: The Case of Turkey," Gazi University Faculty of Economics and Administrative Sciences Journal, vol. 18, no. 3. pp. 762-778, 2016.

[48] R. Belu. "Artificial intelligence techniques for solar energy and photovoltaic applications," Handbook of Research on Solar Energy Systems and Technologies, pp. 376-436, 2012.

[49] I. Ozcan. "Determination of Wind Energy Potential in Isparta Province and Design of a Wind Farm," Master Thesis, Süleyman Demirel University, Isparta. 2011.

[50] M. Alruwaili, S. Alanazi, S. El-Ghany and A. Shehab. "An Efficient Deep Learning Model for Olive Diseases Detection," International Journal of Advanced Computer Science and Applications, vol. 10, no. 8. pp. 486-492, 2019.

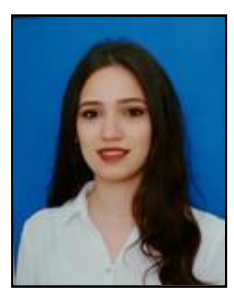

\section{Mrs. Selin Galatali}

Research Assistant in Molecular Biology and Genetics Department (Mugla Sitki Kocman University, Tukey). Her research interests are in the areas of plant biotechnology and plant molecular biology. She investigates cold stress genes of in vitro grown plant species at transcriptional levels.

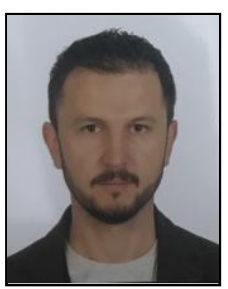

\section{Assoc. Prof. Dr. Mehmet Ali Balci}

He is working with Muğla Sıtkı Koçman University, Faculty of Science, Department of Mathematics. Mehmet Ali holds a joint $\mathrm{PhD}$ degree in Applied Mathematics from Ege University, İzmir, Turkey. He has successfully led several research projects for data analysis methods on social networks and mathematical modeling. His research interests include graph kernel designing for data analysis, network analysis with clustering techniques, machine 
European Journal of Biology and Biotechnology www.ejbio.org

learning with deep diffusive neural networks, and mathematical modeling of social phenomena.

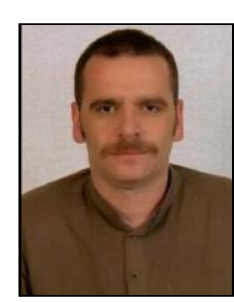

\section{Assist. Prof. Dr. Omer Akguller}

$\mathrm{He}$ is working with Muğla Sitkı Koçman University, Faculty of Science, Department of Mathematics. Ömer holds M.Sc. and PhD degrees in Geometry from Muğla Sitkı Koçman University. His research interests include the geometry of correlation networks, geometric filtration on networks, geometry processing, and manifold learning.

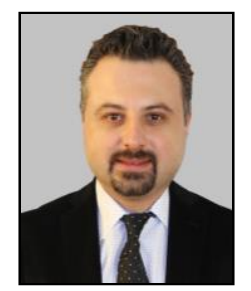

\section{Assoc. Prof. Dr. Ergun Kaya}

He earned his Ph.D. in Molecular Biology and Genetics at Gebze Technical University, Turkey, and served as a post-doctoral fellow in Plant Biotechnology at Colorado State University,

National Center for Genetic Resources Preservation (USA). His primary research interests are plant biotechnology, plant molecular biology. 